\title{
Pengaruh Pemanfaatan Teknologi Informasi dan Kemampuan Teknik Personal Pada Efektivitas SIA
}

\author{
Ni Made Harista Dwi Anggreni1 \\ Fakultas Ekonomi dan Bisnis \\ Universitas Udayana, Indonesia \\ Email: haristadwia@yahoo.com
}

\author{
I Made Sadha Suardikha ${ }^{2}$ \\ Fakultas Ekonomi dan Bisnis \\ Universitas Udayana, Indonesia
}

\begin{abstract}
ABSTRAK
Tujuan dari penelitian ini adalah untuk mengetahui pengaruh Pemanfaatan Teknologi Informasi dan Kemampuan Teknik Personal pada Efektivitas Sistem Informasi Akuntansi. Penelitian ini dilakukan di Dinas Perindustrian dan Perdagangan Kota Denpasar. Teknik analisis yang digunakan adalah teknik analisis regresi linear berganda. Jenis data yang digunakan dalam penelitianini adalah data kuantitatif, yang berupa hasil jawaban oleh responden yang dinyatakan dalam bentuk angka-angka dari kuesioner yang diukur menggunakan skala Likert. Hasil analisis menunjukkan bahwa, pemanfaatan teknologi informasi dan kemampuan teknik personal berpengaruh positif pada efektivitas sistem informasi akuntansi. Hal ini menunjukkan bahwa semakin baik pemanfaatan teknologi informasi dan semakin tinggi kemampuan teknik personal yang dimiliki pegawai Dinas Perindustrian dan Perdagangan Kota Denpasar maka efektivitas sistem informasi akuntansi yang dihasilkan akan semakin meningkat.
\end{abstract}

Kata Kunci: Pemanfaatan Teknologi Informasi; Kemampuan Teknik Personal; Efektivitas Sistem Informasi Akuntansi.

Effect of Utilization of Information Technology and Personal Engineering Capabilities on the Effectiveness of SIA

\begin{abstract}
The purpose of this study was to determine the effect of Utilization of Information Technology and Personal Engineering Capabilities on the Effectiveness of Accounting Information Systems. This research was conducted at the Department of Industry and Trade Denpasar City. The analysis technique used is multiple linear regression analysis techniques. The type of data used in this study is quantitative data, in the form of the results of answers by respondents expressed in the form of numbers from questionnaires that are measured using a Likert scale. The analysis shows that the use of information technology and the ability of personal techniques have a positive effect on the effectiveness of accounting information systems.

Keywords: Utilization Of Information Technology; Personal Technical Ability; Effectiveness of Accounting Information Systems.
\end{abstract}

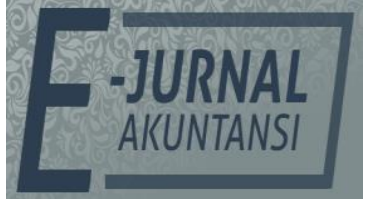

E-JA

e-Jurnal Akuntansi e-ISSN 2302-8556

Vol. 30 No. 6 Denpasar, Juni 2020

Hal.1356-1368

Artikel Masuk: 4 Desember 2019

Tanggal Diterima: 6 Maret 2020

This Article is Avalilable in: https://ojs.unud.ac.id/index.php/Akuntansi/index 


\section{PENDAHULUAN}

Sistem informasi akuntansi adalah komponen dan elemen dari suatu organisasi yang menyediakan informasi bagi pengguna dengan pengolahan peristiwa keuangan (Zare, 2012). Sistem ini akan menjalankan peranannya yaitu dengan memproses data dan mengubahnya menjadi suatu informasi akuntansi yang memiliki nilai tambah dan kemudian akan digunakan oleh berbagai pengguna internal dan pengguna eksternal dalam pengambilan keputusan (Onaolapo \& Odetayo, 2012). Sistem informasi akuntansi bertanggung jawab dalam menganalisa dan memantau kondisi keuangan, persiapan dokumen yang diperlukan untuk keperluan pajak, memberikan informasi untuk mendukung banyak fungsi lainnya, seperti pendataan, penilaian, pembayaran, dan penetapan pajak. Tujuan dalam penyusunan suatu sistem informasi akuntansi antara lain untuk menditalisasi informasi Yuhelson et al., (2020) bagi pengelolaan kegiatan keuangan, memperbaiki informasi yang dihasilkan oleh sistem yang telah ada, baik mengenai mutu, ketepatan penyajian maupun struktur informasinya. Penelitian pada bidang teknologi informasi bertujuan supaya penggunaan teknologi informasi dapat dengan mudah digunakan oleh pengguna akhir (Putra (2012) dan Ariyanto, et al., (2014)

Kualitas SIA dapat dievaluasi dari akurasi, ketepatan waktu, kelengkapan, dan konsistensi (Al-hiyari, 2013). Keberhasilan kinerja antara sistem, pemakai Hastalona, et al., (2019) dan sponsor merupakan penentu efektivitas sistem informasi akuntansi. Meliyawati, (2016) mengemukakan dari hasil penelitian yang telah dilakukan bahwa efektivitas sistem informasi akuntansi akan berpengaruh jika adanya kecanggihan teknologi informasi dalam membantu perusahaan menghasilkan informasi yang cepat dan akurat untuk keputusan yang efektif. Konsisten dengan penelitian sebelumnya, pada penelitian yang dilakukan oleh Gustiyan (2014) menyatakan kinerja sistem informasi akuntansi berpengaruh dan signifikan pada kemampuan teknik personal yang akan meningkatkan efektivitas penggunaan sistem. Faktor-faktor penting yang memengaruhi efektivitas sistem informasi akuntansi diharapkan dapat memberikan pengaruh yang positif dan dapat menunjukkan tingkat keberhasilan sistem dalam menjalankan fungsinya dengan menghasilkan kualitas informasi yang akurat dan dapat dipercaya agar memudahkan pengguna dalam menyelesaikan tugas-tugasnya (Kristiani, 2012).

Pentingnya penggunaan sistem informasi akuntansi yang didukung oleh pemanfaatan teknologi informasi dan pemakai sistem yang baik mendorong sebuahorganisasi untuk menciptakan keunggulan. Dalam pengembangan sistem informasi,para pemakai menjadi fokus penting berkaitan dengan keefektifan sistem informasi akuntansi (Kusumaastuti \& Irwandi, 2012). Keberhasilan sebuah organisasi bukanhanya ditentukan oleh kecanggihan teknologi tersebut, tetapi ditentukan olehkesesuaiannya dengan lingkungan para pemakai sistem yang terlibat. Menurut Setiani (2008) melaksanakan pengembangan sistem informasi akuntansi bertujuan untukmemenuhi kebutuhan informasi instansi dan kepuasan pemakai sistem informasitersebut. Kemampuan teknik pemakai sistem yang baik sangat diharapkan agar dapatmeningkatkan kinerja sistem informasi akuntansi. Pemakai yang handal sertamengetahui perkembangan teknologi 
diharapkan dapat meningkatkan kinerjanya. Kinerja organisasi yang baik tercipta dari para pemakai dalam menjalankan tugasnya tepat waktu.

Perkembangan teknologi informasi memberikan banyak pengaruh terhadap sistem informasi akuntansi karena ada digitalisasi informasi (Yuhelson et al., 2020). Penggunaan teknologi komputer dan internet merupakan salah satu bentuk teknologi informasi yang mampu mengubah proses data secara manual menjadi secara digital dan otomatis (Suhardiyah \& Waryanto, 2014). Kecanggihan teknologi berkembang pesat di masa kini bahkan mampu menghasilkan beraneka ragam sistem yang dirancang dalam membantu menghasilkan kualitas informasi yang baik bagi kebutuhan manusia. Instansi yang terkomputerisasi dan terintegrasi mempunyai teknologi yang di dukung oleh aplikasi pendukung modern yang canggih, mampu memberikan dampak yang positif bagi kinerja instansi dalam membuat laporan keuangan yang akurat, tepat waktu dan dapat dipercaya. Hasil-hasil penelitian sebelumnya yaitu penelitian dari Ismail (2009) menyatakan bahwa kecanggihan SIA tidak berpengaruh signifikan terhadap efektivitas SIA. Perbedaan hasil didapat dari penelitian Dwitrayani (2012) dan Ratnaningsih \& Agung (2014) yang menyatakan bahwa kecanggihan teknologi informasi berpengaruh positif dan signifikan terhadap efektivitas sistem informasi akuntansi.

Kemampuan teknik personal dalam mengoperasikan suatu sistem informasi akuntansi sangat dibutuhkan. Terkadang terjadi kesalahan maupun kegagalan sistem informasi dalam memberikan informasi yang dibutuhkan, dikarenakan kurang tepatnya pengetahuan dan kemampuan yang dimiliki oleh pengguna sistem tersebut. Seorang karyawan dengan tingkat kemampuan teknik personal yang rendah memiliki kinerja di bawah tingkat kemampuan aktualnya dan mengabaikan kemampuannya untuk bekerja lebih baik (Hasan, 2017). Hasilhasil dari penelitian sebelumnya yaitu penelitian Abhimantra \& Suryanawa (2016) menyatakan bahwa kemampuan teknik personal berpengaruh pada kinerja sistem informasi akuntansi pada BPR di Kota Denpasar. Penelitian tersebut juga mendapatkan hasil yang sama dengan penelitian yang dilakukan oleh Adisanjaya et al. (2017) menyatakan terdapat pengaruh positif dan signifikan antara kemampuan personal terhadap efektivitas sistem informasi akuntansi. Perbedaan hasil ditunjukkan pada penelitian Dharmawan \& Ardianto (2017) menyatakan kemampuan teknik personal tidak berpengaruh positif terhadap kinerja efektivitas SIA.

Dinas Perindustrian dan Perdagangan Kota Denpasar merupakan satu sarana pelayanan yang dibentuk oleh Pemerintah guna meningkatkan efesiensi perdagangan dalam negeri. Bantuan yang rutin diberikan oleh Dinas Perindustrian dan Perdagangan adalah dengan mengadakan pelatihan-pelatihan kepada industri kecil dan menengah di Kota Denpasar, hal tersebut guna mencetak wirausaha sebanyak-banyaknya, karena wirausaha terbukti mampu meningkatkan kesejahteraan masyarakat melalui peningkatan pendapatan akibat ekonomi yang berkembang. Dinas Perindustrian dan Perdagangan Kota Denpasar membutuhkan perencanaan dan anggaran sebelum mengadakan suatu pelatihan serta adanya proses pencatatan keuangan setelah mengadakan suatu pelatihan. Perencanaan dan anggaran serta pencatatan keuangan dibantu dengan adanya sistem akuntansi yang terkomputerisasi. Saat ini Dinas Perindustrian dan 
Perdagangan menggunakansistem informasi akuntansi yang diberi nama Sistem Informasi Pengelolaan Keuangan Daerah (SIPKD). SIPKD adalah aplikasi terpadu yang dipergunakan sebagai alat bantupemerintah daerah untuk meningkatkan efektivitas implementasi dari berbagairegulasi bidang pengelolaan keuangan daerah yang berdasarkan asas efisiensi, ekonomis, efektif, transparan, akuntabel, dan auditabel. Dimana Dinas Perindustrian dan Perdagangan Kota Denpasar melaporkan pertanggungjawaban keuangannya kepada BPKAD (Badan Pengelolaan Keuangan dan Aset Daerah) Kota Denpasar. SIPKD diciptakan untuk mempermudah penggunanya dalam pelaporan keuangan, namun di Dinas Perindustrian dan Perdagangan memiliki kendala terkait sistem yang digunakan. Kendalanya pengimplementasian Software SIPKDmasih belum berjalan dengan baik karena kemampuan pegawai yang kurang optimal dalam mengoperasikan Software SIPKDsehingga sering terjadi kesalahan dalam menggunakan Software SIPKD.

Menurut Kepala Sub Bagian Keuangan Dinas Perindustrian dan Perdagangan Kota Denpasar, Made Ari Wilaksani, kemampuan pegawai yang kurang optimal dalam mengoperasikan Software SIPKD karena tidak semua pegawai memahami Software SIPKD, pegawai masih sulit untuk menggunakan Software SIPKD, disiplin kerja pegawai masih kurang dan tidak tepat waktu, pegawai yang mengoperasikan SIPKD berlatar belakang pendidikan akuntansi juga masih minim di bagian keuangan. Sebagian besar pegawai yang mengoperasikan SIPKD berlatar belakang pendidikan sarjana komputer dan sarjana teknik. Akibatnya laporan keuangan yang seharusnya dilaporkan ke BPKAD Kota Denpasar paling lambat tanggal 10 setiap bulannya, akan tetapi di Dinas Perindustrian dan Perdagangan Kota Denpasar sering terjadi keterlambatan melaporkan laporan keuangannya hingga tanggal 17 setiap bulannya. (Disperindag 20/08/19 15:00).

Sistem informasi akuntansi dapat dikatakan efektif apabila sistem mampu menghasilkan informasi yang dapat diterima dan memenuhi harapan secara tepat waktu (timely), akurat (accurate), dan dapat dipercaya (reliable), di mana dalam mewujudkannya dibutuhkan pemanfaatan teknologi informasi yang memadai dan maksimal. Pemanfaatan teknologi informasi adalah pengolahan data, pengolahan informasi dan proses kerja manajemen secara elektronik (Nurillah, 2014).

Ada banyak penelitian mengenai faktor-faktor dalam efektivitas sistem informasi akuntansi. Karmita (2015) mengungkapkan bahwa pemanfaatan teknologi informasi berpengaruh terhadap efektivitas sistem informasi akuntansi. Febrianingsih (2015) berpendapat bahwa pemanfaatan teknologi informasi berpengaruh positif terhadap efektivitas sistem informasi akuntansi. Utami et al. (2015) menyatakan bahwa pemanfaatan teknologi berpengaruh positif dan signifikan terhadap efektivitas implementasi sistem informasi akuntansi.

Putra (2014) mengungkapkan bahwa pemanfaatan teknologi informasi berpengaruh positif yang signifikan terhadap efektivitas sistem informasi akuntansi. Pemanfaatan teknologi inforrmasi dapat membantu dalam peningkatan efektivitas sistem informasi akuntansi. Apabila pengguna mampu 
menguasai teknologi informasi yang tersedia maka efektivitas sistem yang dihasilkan akan lebih maksimal.

Shaheen (2012) yang dikutip oleh Alaryan et al. (2014), bahwa terdapat hubungan positif antara lingkungan, teknologi dan budaya yang mendukung terciptanya efektivitas dan efisiensi sistem informasi akuntansi. Penelitian lain yang menjadi acuan dari penelitian ini adalah penelitian Alaryan et al. (2014).

Alaryan et al. (2014) menyimpulkan bahwa terdapat hubungan positif antara software dan hardware terhadap efektivitas sistem informasi akuntansi. Penelitian tersebut menjelaskan bahwa penggunaan teknologi dapat membantu organisasi dalam mengolah data dan informasi lebih akurat dan tepat waktu.

Keterangan berdasarkan teori sebelumnya membuktikan bahwa uraian dan temuan empiris mengenai teknologi informasi menunjukkan bahwa pengolahan data dengan memanfaatkan teknologi informasi (komputer dan jaringan) akan memberikan banyak keunggulan baik dari sisi keakuratan/ketepatan hasil operasi maupun sebagai mesin multiguna maupun mengurangi kesalahan yang mungkin terjadi saat mencatat transaksi keuangan. Berdasarkan penjelasan tersebut, maka dapat dirumuskan hipotesis pertama sebagai berikut.

$\mathrm{H}_{1}$ : Pemanfaatan teknologi informasi berpengaruh positif pada efektivitas sistem informasi akuntansi.

Technology Acceptance Model (TAM) menjelaskan bahwa terdapat dua faktor yang memengaruhi sikap individu untuk menerima dan menggunakan teknologi, yaitu manfaat dan kemudahan (Davis, 1989). Teori tersebut menunjukan bahwa semakin mengertinya penggun adalam manfaat penggunaan SIA maka pengguna akan menerima dan menggunakan SIA tersebut. Kemampuan teknik personal yang baik maka persepsi kemudahan pengguna (easy of use) akan muncul dan menyatakan bahwa SIA tersebut telah berhasil memberi kemudahan bagi pengguna sehingga pengguna akan menerima sistem yang baru lebih baik dan menggunakan terus sistem tersebut. Manfaat (usefulness) merupakan seseorang percaya bahwa dengan penngunaan sistem tertentu akan meningkatkan kinerjanya.

Pada penggunaan sebuah teknologi diperlukannya kemampuan teknik personal yang memiliki hubungan dengan persepsi kemudahan penggunaan, jika kemampuan teknik personal yang dimiliki tinggi maka akan mempermudah penggunaan suatu sistem. Penggunaan sistem informasi dalam suatu organisasi yang didukung oleh meningkatnya kemampuan personal akan membuat sistem informasi dapat berjalan dengan efektif dan mampu meningkatkan kinerja organisasi.

Hal ini juga didukung dengan penelitian yang dilakukan oleh Prabowo et al., (2014), Fani et al., (2015), Wilayanti \& Dharmadiaksa (2016), Yesa (2016), Adisanjaya et al. (2017) dan Suartika \& Sari (2017) yang memperoleh hasil bahwa kemampuan teknik personal berpengaruh positif dan signifikan terhadap efektivitas sistem informasi. Hasil dari penelitian Hutama \& Trisnawati (2017) menghasilkan kemampuan teknik personal berpengaruh secara signifikan terhadap kinerja sistem informasi akuntansi. Dimana kemampuan teknik personal disini berkaitan dengan kemampuan yang dimiliki oleh pemakai sistem informasi akuntansi, sehingga semakin tinggi kemampuan teknik personal 
seseorang maka akan meningkatlan efektivitas sistem informasi akuntansi yang ada. Oleh karena itu, untuk mengurangi terjadinya kesalahan dalam memproses sejumlah transaksi setiap karyawan diharapkan dapat menguasai penggunaan sistem berbasis sehingga laporan keuangan yang dihasilkan dapat tepat waktu dan bermanfaat (Dewi, 2011). Berdasarkan uraian maka dapat dirumuskan hipotesis kedua yang akan diuji sebagai berikut:

$\mathrm{H}_{2}$ : Kemampuan teknik personal berpengaruh positif pada efektivitas sistem informasi akuntansi.

\section{METODE PENELITIAN}

Penelitian ini dilakukan di Dinas Perindustrian dan Perdagangan Kota Denpasar yang beralamat di Gedung Sewaka Dharma Lt. III Jl. Majapahit No. I Lumintang, Denpasar. Adapun objek dari penelitian ini adalah efektivitas sistem informasi akuntansi di Dinas Perindustrian dan Perdagangan Kota Denpasar.

Populasi dalam penelitian ini adalah pengguna sistem informasi akuntansi pada Dinas Perindustrian dan Perdagangan Kota Denpasar yang berjumlah 40 pengguna. (Disperindag Kota Denpasar). Metode penentuan sampel yang digunakan non-probability sampling, yaitu teknik sampling jenuh. Sampel dalam penelitian ini berjumlah 40 pengguna.

Analisis regresi linear berganda digunakan untuk mengetahui pengaruh antara variabel independen dengan variabel dependen, apakah masing-masing variabel independen berhubungan positif atau negatif. Adapun model rumus yang digunakan adalah sebagai berikut.

$$
Y=\alpha+\beta_{1} X_{1}+\beta_{2} X_{2}+\varepsilon
$$

Keterangan:

$$
\begin{array}{ll}
\mathrm{Y} & =\text { Efektivitas Sistem Informasi Akuntansi } \\
\mathrm{a} & =\text { Konstanta } \\
\beta_{1}-\beta_{2} & =\text { Koefisien regresi } \\
\mathrm{X}_{1} & =\text { Pemanfaatan Teknologi Informasi } \\
\mathrm{X}_{2} & =\text { Kemampuan Teknik Personal } \\
\varepsilon & =\text { Error Term, yaitu tingkat kesalahan penduga dalam penelitian }
\end{array}
$$

\begin{tabular}{|c|c|c|c|c|c|}
\hline \multirow[t]{2}{*}{ Model } & \multicolumn{2}{|c|}{$\begin{array}{l}\text { Unstandardized } \\
\text { Coefficients }\end{array}$} & $\begin{array}{l}\text { Standardized } \\
\text { Coefficients }\end{array}$ & \multirow[b]{2}{*}{$\mathrm{t}$} & \multirow[b]{2}{*}{ Sig. } \\
\hline & $B$ & Std. Error & Beta & & \\
\hline \multirow{3}{*}{$\begin{array}{l}\text { (Constant) } \\
\text { Pemanfaatan } \\
\text { informasi } \\
\text { Kemampuan }\end{array}$} & 11,033 & 3,071 & & 3,592 & 0,001 \\
\hline & teknologi0,567 & 0,200 & 0,442 & 2,828 & 0,008 \\
\hline & kpersonal0,521 & 0,215 & 0,380 & 2,428 & 0,020 \\
\hline
\end{tabular}

\section{HASIL DAN PEMBAHASAN}

Perhitungan koefisien regresi linier berganda dilakukan dengan analisis regresi melalui software SPSS 18.0 for Windows, diperoleh hasil yang ditunjukan pada Tabel 1.

Tabel 1. Hasil Analisis Regresi Linier Berganda

Sumber: Data Penelitian, 2019 
Berdasarkan hasil analisis regresi linier berganda seperti yang disajikan pada Tabel 1. maka dapat dibuat persamaan regresi sebagai berikut:

$$
Y=11,033+0,567 X_{1}+0,521 X_{2}
$$

Nilai konstanta 11,033 memiliki arti apabila pemanfaatan teknologi informasi dan kemampuan teknik personal konstan, maka efektivitas sistem informasi akuntansi meningkat sebesar 11,033 satuan. Nilai koefisien regresi pemanfaatan teknologi informasi $X_{1}$ sebesar 0,567 memiliki arti apabila pemanfaatan teknologi informasi meningkat sebesar 1 satuan dengan anggapan variabel lainnya konstan, maka efektivitas sistem informasi akuntansi meningkat sebesar 0,567 satuan.Nilai koefisien kemampuan teknik personal $\mathrm{X}_{2}$ sebesar 0,521 memiliki arti apabila kemampuan teknik personal meningkat sebesar 1 satuan dengan anggapan variabel lainnya konstan, maka efektivitas sistem informasi akuntansi meningkat sebesar 0,521 satuan.

Dari Tabel 1. diperoleh bahwa variabel pemanfaatan teknologi informasi memberikan nilai koefisien sebesar 0567 dengan probabilitas signifikansi 0,008. Variabel kemampuan teknik personal memberikan nilai koefisien sebesar 0,521 dengan probabilitas signifikansi 0,020. Kedua variabel ini dapat disimpulkan berpengaruh positif terhadap efektivitas sistem informasi akuntansi, karena tingkat signifikansi $\mathrm{F} \leq 0,05$.

Uji kelayakan model regresi bertujuan untuk mengetahui apakah semua variabel bebas yang diidentifikasi (pemanfaatan teknologi informasi, dan kemampuan teknik personal) tepat digunakan memprediksi efektivitas sistem informasi akuntansi. Uji ini sering juga disebut dengan uji F. Adapun hasil uji F dapat dilihat pada Tabel 2. berikut:

Tabel 2. Hasil Uji F (Annova)

\begin{tabular}{|c|c|c|c|c|c|c|}
\hline \multirow{2}{*}{$\overline{1}$} & Model & \multicolumn{2}{|c|}{ Sum of Squaresdf } & \multirow{3}{*}{$\begin{array}{l}\text { Mean Square } \\
135.458\end{array}$} & \multirow{2}{*}{$\frac{F}{26.370}$} & \multirow{2}{*}{$\frac{\text { Sig. }}{.000^{\mathrm{a}}}$} \\
\hline & Regression & 270.915 & 2 & & & \\
\hline & Residual & 190.060 & 37 & & & \\
\hline & Total & 460.975 & 39 & & & \\
\hline
\end{tabular}

Sumber: Data Penelitian, 2019

Hasil uji $\mathrm{F}$ yang di analisis dengan menggunakan program SPSS

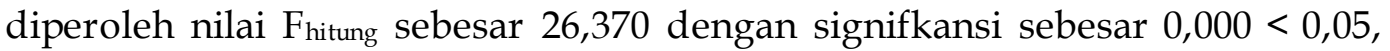
maka dapat disimpulkan bahwa pada kelompok yang diuji memiliki perbedaan yang nyata (signifikan). Hasil ini mempunyai arti bahwa ada pengaruh signifikan antara pemanfaatan teknologi informasi dan kemampuan teknik personal secara simultan terhadap efektivitas sistem informasi akuntansi pada Dinas Perindustrian dan Perdagangan Kota Denpasar.

Koefisien determinasi $\left(\mathrm{R}^{2}\right)$ digunakan untuk mengetahui dan mengukur kemampuan model dalam menerangkan variasi variabel independen. Besarnya pengaruh variabel bebas terhadap variabel terikat yang ditunjukkan oleh nilai determinasi total (R Square) pada Tabel 3. berikut:

Tabel 3. Hasil Uji Koefisien Determinasi

\begin{tabular}{clllllr}
\hline Model & & & & Std. Error of the \\
& $R$ & $R$ Square & Adjusted R Square & Estimate & \\
\hline 1 & .767 a & .588 & .565 & 2.26644 & \\
\hline
\end{tabular}

Sumber: Data Penelitian, 2019 
Tabel 3. Hasil Uji Koefisien Determinasi menunjukkan nilai Adjusted R Square sebesar 0,565, yang berarti bahwa sebesar 56,5\% variasi efektivitas sistem informasi akuntansi pada Dinas Perindustrian dan Perdagangan Kota Denpasar dipengaruhi oleh variasi pemanfaatan teknologi informasi dan kemampuan teknik personal, sedangkan sisanya sebesar $43,5 \%$ djelaskan oleh faktor lain yang tidak dimasukkan ke dalam model.

Tabel 4. Hasil Uji Hipotesis (Uji t)

\begin{tabular}{llllllr}
\hline \multicolumn{1}{c}{ Model } & \multicolumn{2}{c}{$\begin{array}{c}\text { Unstandardized } \\
\text { Coefficients }\end{array}$} & $\begin{array}{c}\text { Standardized } \\
\text { Coefficients }\end{array}$ & & \\
\cline { 2 - 5 } & \multicolumn{1}{c}{$B$} & Std. Error & Beta & $t$ & Sig. \\
\hline 1 & 11,033 & 3,071 & & 3,592 & 0,001 \\
& $\begin{array}{l}\text { (Constant) } \\
\begin{array}{l}\text { Pemanfaatan teknologi } \\
\text { informasi }\end{array}\end{array}$ & 0,567 & 0,200 & 0,442 & 2,828 & 0,008 \\
$\begin{array}{l}\text { Kemampuan teknik } \\
\text { personal }\end{array}$ & 0,521 & 0,215 & 0,380 & 2,428 & 0,020 \\
\hline
\end{tabular}

Sumber: Data Penelitian, 2019

Berdasarkan hasil analisis pengaruh pemanfaatan teknologi informasi terhadap efektivitas sistem informasi akuntansi diperoleh nilai signifikasi sebesar 0,008 dengan nilai koefisien regresi yang bernilai positif sebesar 0,567 . Nilai Signifikansi 0,008 <0,050 mengindikasikan bahwa $\mathrm{H}_{1}$ diterima. Berdasarkan hasil analisis pengaruh kemampuan teknik personal terhadap efektivitas sistem informasi akuntansi diperoleh nilai signifikansi sebesar 0,020 dengan nilai koefisien regresi yang bernilai positif sebesar 0,521. Nilai Signifikansi 0,030<0,050 mengindikasikan bahwa $\mathrm{H}_{2}$ diterima.

Hasil analisis menunjukkan bahwa pemanfaatan teknologi informasi berpengaruh positif terhadap efektivitas sistem informasi akuntansi, yakni semakin baik pemanfaatan teknologi informasi berdasarkan intensitas pemanfaatan, frekuensi pemanfaatan, dan jumlah aplikasi atau perangkat lunak yang digunakan pada Dinas Perindustrian dan Perdagangan Kota Denpasar maka efektivitas sistem informasi akuntansi yang dihasilkan akan semakin meningkat. Begitu pula sebaliknya, semakin tidak baik pemanfaatan teknologi informasi pada Dinas Perindustrian dan Perdagangan Kota Denpasar, maka akan semakin menurunkan efektivitas sistem informasi akuntansi.

Hasil ini mendukung penelitian yang dilakukan oleh Putra (2014) yang mengungkapkan bahwa pemanfaatan teknologi informasi berpengaruh positif yang signifikan terhadap efektivitas sistem informasi akuntansi. Pemanfaatan teknologi inforrmasi dapat membantu dalam peningkatan efektivitas sistem informasi akuntansi. Apabila pengguna mampu menguasai teknologi informasi yang tersedia maka efektivitas sistem yang dihasilkan akan lebih maksimal. Hasil penelitian ini juga sesuai dengan temuan Karmita (2015), Febrianingsih (2015) dan Utami et al. (2015) menyatakan bahwa pemanfaatan teknologi berpengaruh positif dan signifikan terhadap efektivitas implementasi sistem informasi akuntansi.

Penelitian serupa oleh Shaheen (2012) dan Alaryan et al. (2014) juga menyimpulkan bahwa terdapat hubungan positif antara software dan hardware terhadap efektivitas sistem informasi akuntansi. Penelitian tersebut menjelaskan bahwa penggunaan teknologi dapat membantu organisasi dalam mengolah data 
dan informasi lebih akurat dan tepat waktu. Keterangan pada penelitian sebelumnya membuktikan bahwa uraian dan temuan empiris mengenai teknologi informasi menunjukkan bahwa pengolahan data dengan memanfaatkan teknologi informasi (komputer dan jaringan) akan memberikan banyak keunggulan baik dari sisi keakuratan/ketepatan hasil operasi maupun sebagai mesin multiguna maupun mengurangi kesalahan yang mungkin terjadi saat mencatat transaksi keuangan.

Hasil analisis menunjukkan bahwa kemampuan teknik personal berpengaruh positif terhadap efektivitas sistem informasi akuntansi, yang berarti bahwa semakin tinggi kemampuan teknik personal yang dimiliki oleh pegawai Dinas Perindustrian dan Perdagangan Kota Denpasar maka efektivitas sistem informasi akuntansi yang dihasilkan akan semakin meningkat. Memiliki kemampuan teknik personal yang baik dilihat dari pengetahuan, kemampuan dan keahliannya akan mendorong pengguna untuk menggunakan sistem informasi akuntansi sehingga kinerja sistem informasi akuntansi lebih tinggi. Secara umum kemampuan teknik personal sangat dibutuhkan untuk menunjukkan sejauh mana kualitas pribadi seseorang dan penguasaan sistem dalam menguasai teknik pengelolaan sistem informasi akuntansi yang dikembangkan. Begitu pula sebaliknya, semakin rendah kemampuan teknik personalseorang pegawai, maka semakin rendah tingkat efektivitas sistem informasi akuntansi tersebut.

Temuan ini sesuai dengan penelitian Hutama \& Trisnawati (2017) yang menyatakan bahwa kemampuan teknik personal berpengaruh secara signifikan terhadap kinerja sistem informasi akuntansi. Dimana kemampuan teknik personal disini berkaitan dengan kemampuan yang dimiliki oleh pemakai sistem informasi akuntansi, sehingga semakin tinggi kemampuan teknik personal seseorang maka akan meningkatlan efektivitas sistem informasi akuntansi yang ada. Oleh karena itu, untuk mengurangi terjadinya kesalahan dalam memproses sejumlah transaksi setiap karyawan diharapkan dapat menguasai penggunaan sistem berbasis sehingga laporan keuangan yang dihasilkan dapat tepat waktu dan bermanfaat (Dewi, 2011).

Hasill ini juga didukung dengan penelitian yang dilakukan oleh Prabowo et al., (2014), Fani et al., (2015), Wilayanti \& Dharmadiaksa (2016), Yesa (2016), Adisanjaya et al. (2017) dan Suartika \& Sari (2017) yang memperoleh hasil bahwa kemampuan teknik personal berpengaruh positif dan signifikan terhadap efektivitas sistem informasi. Pada penggunaan sebuah teknologi diperlukannya kemampuan teknik personal yang memiliki hubungan dengan persepsi kemudahan penggunaan, jika kemampuan teknik personal yang dimiliki tinggi maka akan mempermudah penggunaan suatu sistem. Penggunaan sistem informasi dalam suatu organisasi yang didukung oleh meningkatnya kemampuan personal akan membuat sistem informasi dapat berjalan dengan efektif dan mampu meningkatkan kinerja organisasi.

Penelitian yang dilakukan diharapkan dapat memberikan kontribusi mengenai analisis faktor - faktor yang mempengaruhi efektivitas sistem informasi akuntansi pada Dinas Perindustrian dan Perdagangan Kota Denpasar. Hasil uji hipotesis dalam penelitian ini ditemukan bahwa pemanfaatan teknologi informasi dan kemampuan teknik personal secara statistik memiliki pengaruh 
yang positif dan signifikan pada efektivitas sistem informasi akuntansi pada Dinas Perindustrian dan Perdagangan Kota Denpasar, sehingga hal tersebut sesuai dengan kajian penelitian terdahulu dan sesuai dengan teori Technology Acceptance Model (TAM), dimana teori tersebut menunjukkan bahwa semakin mengertinya personal atas manfaat yang diberikan oleh pengguna sistem informasi akuntansi maka personal akan menerima dan menggunakan sistem informasi akuntansi dan pada akhirnya efektivitas sistem informasi akuntansi akan semakin meningkat.

Penelitian ini memberikan implikasi bagi Dinas Perindustrian dan Perdagangan Kota Denpasar sebagai pertimbangan dan pengetahuan mengenai efektivitas sistem informasi akuntansi pada Dinas Perindustrian dan Perdagangan Kota Denpasar serta faktor-faktor yang memengaruhinya. Instansi dapat mengevaluasi serta meningkatkan pemanfaatan teknologi informasi dan kemampuan teknik personal, karena hal tersebut dapat mempengaruhi efektivitas sistem informasi akuntansi pada Dinas Perindustrian dan Perdagangan Kota Denpasar.

Terdapat keterbatasan yang mempengaruhi kondisi dari penelitian yang dilakukan. Adapun keterbatasan dalam penelitian ini yaitu Faktor-faktor yang mempengaruhi efektivitas sistem informasi akuntansi dalam penelitian ini hanya terdiri dari dua variabel bebas, yaitu pemanfaatan teknologi informasi dan kemampuan teknik personal. Sedangkan masih ada faktor lain yang berkaitan dengan efektivitas sistem informasi akuntansi dan dapat dianalisis bersamasama untuk menilai keterkaitannya dengan efektivitas sistem informasi akuntansi.

\section{SIMPULAN}

Berdasarkan hasil penelitian dan pembahasan pada bab sebelumnya maka dapat disimpulkan bahwa pemanfaatan teknologi informasi berpengaruh positif terhadap efektivitas sistem informasi akuntansi, yakni berarti semakin baik pemanfaatan teknologi informasi pada Dinas Perindustrian dan Perdagangan Kota Denpasar maka efektivitas sistem informasi akuntansi yang dihasilkan akan semakin meningkat. Begitu pula sebaliknya, semakin tidak baik pemanfaatan teknologi informasi pada Dinas Perindustrian dan Perdagangan Kota Denpasar, maka akan semakin menurunkan efektivitas sistem informasi akuntansi.

Kemampuan teknik personal berpengaruh positif terhadap efektivitas sistem informasi akuntansi, yang berarti bahwa semakin tinggi kemampuan teknik personal yang dimiliki oleh pegawai Dinas Perindustrian dan Perdagangan Kota Denpasar maka efektivitas sistem informasi akuntansi yang dihasilkan akan semakin bertambah. Begitu pula sebaliknya, semakin rendah kemampuan teknik personal seorang pegawai, maka semakin rendah tingkat efektivitas sistem informasi akuntansi tersebut.

\section{REFERENSI}

Abhimantra, W. P., \& Suryanawa, I. K. (2016). Analisis Faktor-faktor Yang Memengaruhi Kinerja Sistem Informasi Akuntansi. E-Jurnal Akuntansi Udayana, 14(3), 1782-1809.

Adisanjaya, K., Wahyuni, M. A., \& Purnamawati, G. A. (2017). Pengaruh 
Kemampuan Personal, Pelatihan Dan Pendidikan Serta Pemanfaatan Teknologi Terhadap Efektivitas Sistem Informasi Akuntansi Pada Mini Market Bali Mardana. Jurnal Ilmiah Mahasiswa Akuntansi, 7(1).

Al-hiyari, A. (2013). Factors that Affect Accounting Information System Implementation and Accounting Information Quality: A Survey in University Utara Malaysia. American Journal of Economics, 3(1), 27-31.

Alaryan, L. A., Haija, A., \& Taber, T. (2014). The Effectiveness of Accounting Infomation Systems in Jordanian Private Higher Education Institutions. International Journal of Accounting and Financial Reporting, 4(1).

Ariyanto, D., Subroto, B., Purnomosidhi, B., \& Rosidi. (2014). Does the Balinese Tri Hita Karana Culture Affect the Adoption and Usage of Information Technology Systems? Information and Knowledge Management, 4(9), 1-18. https://doi.org/10.1590/S1516-18462008000300012

Davis, F. D. (1989). Perceived Usefulness, Perceived Ease of Use, and User Acceptance of Information Technology.

Dewi, A. N. W. (2011). Pengaruh Tingkat Pendidikan, Pelatihan, dan Pengalaman Kerja Karyawan pada efektivitas Sistem Informasi Akuntansi Pada The Westin Resort Nusa Dua Bali. E-Journal Fakultas Ekonomi Universitas Udayana.

Dharmawan, J., \& Ardianto, J. (2017). Pengaruh Kemutakhiran Teknologi, Kemampuan Teknik Personal Sistem Informasi, Program Pelatihan Pengguna Dan Dukungan Manajemen Puncak Terhadap Kinerja Sistem Informasi Akuntansi (Studi Empiris Pada Karyawan Perusahaan Retail Consumer Goods Wilayah Tangera. Ultima Accounting, 9(1).

Dwitrayani, M. C. (2012). Pengaruh Kecanggihan TI dan Partisipasi Manajemen terhadap Efektivitas Sistem Informasi Akuntansi BPR di Kabupaten Badung. Skripsi Fakultas Ekonomi Universitas Udayana Denpasar.

Fani, N. Y., Surya, D., \& Purnamawati, G. A. (2015). Pengaruh Kecanggihan Teknologi Informasi, Kemampuan Teknik Pemakai, Dan Dukungan Manajemen Puncak Terhadap Kinerja Sistem Informasi Akuntansi Studi Empiris pada PT PLN (Persero) Area Bali Utara(Kantor Pusat). Jurnal Ilmiah Mahasiswa Akuntansi, 3(1).

Gustiyan, H. (2014). Analisis faktor-faktor yang memengaruhi Kinerja Sistem Informasi Akuntansi pada Bank Perkreditan Rakyat (BPR) di Tanjungpinang. Jurnal Akuntansi.

Hastalona, D., Iswanto, A. H., Ariyanto, D., Prastyorini, J., \& Bi Rahmani, N. A. (2019). The Effect of Sustainable Practices in Supply Chain Department on Organisational Performance. International Journal of Innovation, Creativity and Change, 9(5), 60-79.

Hutama, R. C., \& Trisnawati, R. (2017). Pengaruh Keterlibatan Pemakai Sistem, Program Pelatihan dan Pendidikan, Kemampuan Teknik Personal, Dukungan Manajemen Puncak, dan Formalisasi Pengembangan Sistem Informasi Terhadap Efektivitas Sistem Informasi Akuntansi di Bank Umum Kota Surakarta. Dissertasi Universitas Muhammadiyah Surakarta.

Ismail, N. A. (2009). Factors Influencing AIS Effectiveness among Manufacturing Smes: Evidence from Malaysia. The Electronic Journal on Information Systems in Developing Countries, 38(10), 1-19. 
Karmita, F. (2015). Pengaruh Pemanfaatan Teknologi Informasi dan Kompetensi Sumber Daya Manusia terhadap Efektivitas Sistem Informasi Akuntansi. EJurnal Akuntansi Universitas Udayana.

Kristiani, W. (2012). Analisis Pengaruh Efektivitas Teknologi Sistem Informasi Akuntansi Terhadap Kinerja Individual Pegawai PT. Kim Eng Sekuritas Indonesia. Jurnal Akuntansi Ekonomi Dan Bisnis.

Kusumaastuti, M. C., \& Irwandi, S. A. (2012). Investigasi Empat Faktor Kontingensi Sebagai Variabel Moderating Terhadap Partisipasi Pemakai dan Kepuasan Pemakai Dalam Pengembangan Sistem Informasi. Jurnal Akuntansi Fakultas Ekonomi STIE Parbanas, 2(2), 139-150.

Meliyawati, M. (2016). Pengaruh Kecanggihan Teknologi Informasi, Partisipasi Manajemen, Dan Pengetahuan Manajer Akuntansi Terhadap Efektivitas Sistem Informasi Akuntansi (Studi Pada Pt Pln (Persero) Distribusi Jawa Barat Dan Banten). Dissertasi Fakultas Ekonomi Universitas Pasundan Bandung. Nurillah. (2014). Pengaruh Kompetensi Sumber Daya Manusia, Penerapan Sistem Akuntansi Keuangan Daerah, Pemanfaatan Teknologi Informasi, dan Sistem Pengendalian Intern terhadap Kualitas Laporan Keuangan Daerah. Skripsi Fakultas Ekonomika Dan Bisnis Universitas Diponegoro.

Onaolapo, A. A., \& Odetayo, T. A. (2012). Effect of Accounting Information System on Organisational Effectiveness: A Case Study of Selected Construction Companies in Ibadan, Nigeria. American Journal of Business and Management, 1(4), 183-189.

Prabowo, G. R., Amir, M., \& Henny, M. (2014). Faktor-faktor yang Mempengaruhi Kinerja Sistem Informasi Akuntansi (Studi Kasus pada Lingkungan Pemerintahan Kabupaten Temanggung). Accounting Analysis Journal.

Putra, N. P. (2012). Analisis Faktor-faktor yang Memengaruhi Kinerja Sistem Informasi Akuntansi (Studi Kasus PT. Citra Indonesia Feedmill. Jurnal Ilmiah Universitas Gunadarma.

Ratnaningsih, I., \& Agung, S. (2014). Pengaruh Kecanggihan Teknologi Informasi, Partisipasi Manajemen, Dan Pengetahuan Manajer Akuntansi Pada Efektivitas Sistem Informasi Akuntansi. E- Jurnal Akuntansi Universitas Udayana, 6(1), 1-16.

Setiani, K. O. (2008). Pengaruh Dukungan Manajemen Puncak dan Partisipasi Pengguna Terhadap Kepuasan Pengguna Sistem Informasi Akuntansi Pada PTTelkomunikasi Tbk. Di Surabaya. Skripsi Sekolah Tinggi Ilmu Ekonomi Perbanas.

Suartika, K. A., \& Sari, W. N. L. (2017). Kemampuan Teknik Personal Pada Efektivitas Penggunaan Sistem Informasi Akuntansi Dengan Pendidikan Dan Pelatihan Sebagai Pemoderasi. E-Jurnal Akuntansi Universitas Udayana, 18(2), 1485-1512.

Suhardiyah, M., \& Waryanto, B. D. (2014). Analisis Faktor-Faktor yang Memengaruhi Kinerja Sistem Informasi Akuntansi (Studi Kasus pada Universitas PGRI Adi Buana Surabaya). Majalah Ekonomi UNIPA Surabaya, 19(1).

Wilayanti, N. W., \& Dharmadiaksa, I. B. (2016). Keterlibatan Dan Kemampuan Teknik Personal Pada Efektivitas Penggunaan Sistem Informasi Akuntansi. 
E-Jurnal Akuntansi Universitas Udayana, 15(2), 1310-1337.

Yesa, T. A. P. (2016). Pengaruh Partisipasi Pemakai dan Kemampuan Teknik Personal Akuntansi Terhadap Kinerja Sistem Informasi Akuntansi (Studi Empiris BUMN pada Kota Padang Provinsi Sumatera Barat). Jurnal Akuntansi, 4(2).

Yuhelson, Ariyanto, D., Ernawati, Soejono, F., \& Dewi, S. P. (2020). Digital economy and financial inclusion. Journal of Environmental Treatment Techniques, 8(1), 241-243.

Zare, I. (2012). Study of Effect of Accounting Information System and Softwares on Qualitative Features of Accounting Information. Journal of Management Science and Business Research, 1(4), 1-12. 